\title{
LABORATORY AIDS IN STEROID THERAPY
}

\author{
BY \\ J. H. GLYN \\ Arthur Stanley Institute, Middlesex Hospital
}

(RECEIVED FOR PUBLICATION AUGUST 18, 1956)

\section{Introduction}

Cortisone and its analogues have been available in Great Britain for about 6 years. Despite extensive experience, it has not yet been possible to codify precisely either the indications for using these drugs or the method of regulating their dosage for maintenance therapy in the chronic rheumatic diseases. Nevertheless, the success or failure of treatment frequently depends on the refinements of these two factors.

The problem is complicated by the fact that several of the traditional and objective criteria of disease activity are not relevant when using the steroid drugs. For example, Vaughan, Bayles, and Favour (1951) wrote: “ . . . It will be wiser to use the sedimentation rate in parallel with the eosinophil count merely as an index of continued hormonal activity and not as a criterion of the effectiveness of therapy or disease activity." Bagnall (1951) reported a rise in the sedimentation rate of twelve patients, all of whom showed undoubted clinical improvement. Copeman and others (1952) further emphasized the unreliability of this test ". . . except as an indication of general trends". These workers have also pointed out that the degree of anaemia, as represented by the haemoglobin concentration, may no longer be used as a measure of disease activity. It may be profoundly influenced, especially in the early stages of treatment, by irrelevant and pharmacologically-induced phenomena.

It is also true that these drugs invalidate several clinical criteria of the progress of the disease. For example, a gain in weight in a patient under treatment may be an ominous warning of sodium retention rather than an encouraging sign of diminished toxicity, and the suppression of a fever has to be interpreted quite differently from the occurrence of the same physical sign in an untreated patient.

The prognosis of rheumatoid arthritis is notorious- ly unpredictable. Since it is generally agreed that these powerful drugs should only be employed in patients in whom the disease might otherwise run a progressive or crippling course, there is, to quote Ragan, Demartini, Lamont-Havers, Jessar, Vaillancourt, and Grokoest (1952): “ . . . a crying need for some definitive index of a poor prognosis early in the disease. If this were available, the tools are at hand to prevent invalidism at least for some years".

The investigation here reported was designed to overcome some of these difficulties. It was also hoped to throw some light on the vexed problem o\& knowing when steroid therapy can be safely ter minated. It is often difficult to know the extent tळ which the disease has gone into a natural remission as opposed to a drug-induced remission. A premature withdrawal of the drugs may have serious consequences which are difficult to reverse. Finally, it was hoped that one or more of these tests might prove helpful in "screening" the new drugs which are launched on to the market each year and for which "anti-rheumatic" properties are claimed.

\section{Material}

During the last few years a large number of non-specific serological anomalies have been described in association with inflammatory or necrotic processes. They have been generically labelled "acute phase reactions", and claims have been made that fluctuations in the level of several of them run parallel to the severity of the conditions which provoked them. A selection of these tests was applied to seventy patients suffering from various collagen vascular diseases in whom anomalous situations had arisen either during or after steroid therapy. In eight of these patients, the tests were performed serially during the first few months of receiving these drugs. It is this group whose results are analysed below.

Only one major criterion was used in selecting the tests to be studied, namely that they should be sufficiently simple to be used routinely if they proved helpful. The tests selected on this basis are listed in Table I (opposite). 
TABLE I

TESTS EMPLOYED AND NORMAL VALUES

\begin{tabular}{|c|c|c|c|c|c|c|}
\hline \multirow{2}{*}{\multicolumn{2}{|c|}{ Reaction }} & \multicolumn{2}{|l|}{ Method Employed } & \multirow{2}{*}{$\begin{array}{l}\text { Highest Value } \\
\text { in Normal } \\
\text { Controls }\end{array}$} & \multicolumn{2}{|c|}{ Clinical Application Described by } \\
\hline & & Authors & Date & & Authors & Date \\
\hline Serum Hexosamine & $\cdots$ & Elson and Morgan & 1933 & 100 mg. per cent. & $\begin{array}{l}\text { Boas and Soffer } \\
\text { Kelley } \\
\text { Boas and Peterman }\end{array}$ & $\begin{array}{l}1951 \\
1952 \\
1953\end{array}$ \\
\hline Serum Mucoprotein & $\cdots$ & Winzler and Smyth & 1948 & 4 mg. per cent. & $\begin{array}{l}\text { Adams and Dwan } \\
\text { Good, Good, Kelley and } \\
\text { Glick } \\
\text { Kelley, Kerschvink, and Ely } \\
\text { Weimer and Redlich Moshin }\end{array}$ & $\begin{array}{l}1950 \\
1950 \\
1952 \\
1953\end{array}$ \\
\hline $\begin{array}{c}\text { Total Protein-bound } \\
\text { saccharides }\end{array}$ & Poly- & $\begin{array}{l}\text { Shetlar, modified by } \\
\text { Badin, Jackson, and } \\
\text { Schubert }\end{array}$ & 1953 & $100 \mathrm{mg}$. per cent. & $\begin{array}{l}\text { Badin and Glyn } \\
\text { Payne, Shetlar, Bullock, } \\
\text { Patrick, Hellbaum and } \\
\text { Ishmael }\end{array}$ & $\begin{array}{l}1954 \\
1954\end{array}$ \\
\hline \multicolumn{2}{|c|}{ Erythrocyte Sedimentation Rate . . } & Westergren & $? ? ?$ & $\begin{array}{l}10 \mathrm{~mm} . \text { females } \\
15 \mathrm{~mm} . \text { males }\end{array}$ & $\begin{array}{l}\text { Ham and Curtis } \\
\text { Lawrence }\end{array}$ & $\begin{array}{l}1938 \\
1953\end{array}$ \\
\hline Plasma Fibrinogen & $\cdots$ & Cullen and Van Slyke & 1920 & $400 \mathrm{mg}$. per cent. & $\begin{array}{l}\text { Fletcher, Dauphinee, and } \\
\text { Ogryzlo } \\
\text { Fearnley } \\
\text { Fearnley and Bunim }\end{array}$ & $\begin{array}{l}1952 \\
1951 \\
1951\end{array}$ \\
\hline “C'"-Reactive Protein & $\cdots$ & Anderson and McCarty & 1950 & $\begin{array}{l}\text { Normal }=0 \\
\text { Range }=0-4\end{array}$ & $\begin{array}{l}\text { Bunim, Kuttner, Baldwin, } \\
\text { and McEwen } \\
\text { Hill } \\
\text { Stollerman and others } \\
\text { Roantree and Rantz }\end{array}$ & $\begin{array}{l}1952 \\
1951 \\
1953 \\
1955\end{array}$ \\
\hline Serum Resorcidin Turbid & ity Test & Badin and Choukroun & 1950 & 70 units & Badin and Choukroun & 1950 \\
\hline
\end{tabular}

\section{Methods}

Initially, the tests were performed twice weekly, but later once weekly estimations were considered to be sufficient. On each occasion when the blood was drawn a full clinical assessment was made.

Subjective Assessment.-This consisted of an overall subjective appraisal by the patient on a scale of 100-0 per cent., the score on the first day of treatment being arbitrarily taken as 100 per cent. in each case.

Objective Assessment.-This was scaled in parallel as follows:

The six most tender, the six most swollen, and the six joints with the most limited movements were selected for serial measurements. Each one was marked out of a total of four points for the characteristics mentioned. Exactly the same method of marking was applied to six appropriate functional tests, and the grip test was also divided into four standards. The total number of points in each group was then added up and expressed as a percentage of the total possible points, assuming the joints to be maximally involved according to our criteria. The resulting figures were then averaged together and scaled up to read 100 per cent. on the first day of treatment.

In this way, all subsequent assessments could be expressed as a percentage of improvement or deterioration as compared with the first day of treatment.
This index is naturally rather a crude one, but it gave consistent results in this series which corresponded with the clinical impression of the patients' progress.

Charts illustrating the correlations between the laboratory tests and the clinical progress were drawn in each of the eight cases. Two of these have been selected for analysis because they illustrate general trends which were constant throughout the group. They also demonstrate certain specific points which seem important.

Fig. 1 (overleaf) concerns a 60-year-old woman with a 2-year history of severe progressive rheumatoid arthritis which had not proved amenable to conventional treatments. Her early response to large doses of hydrocortisone was extremely satisfactory. so that within about 2 weeks she had minimal signs and symptoms.

Corresponding with the clinical suppression there was a very notable fall in the laboratory indices. At this stage there was considerable discussion whether the drug had induced a remission. It is interesting to note, therefore, that, unlike the other indices, the hexosamine, the Winzler mucoprotein, and the total polysaccharides, whilst approaching normal levels, never actually reached them.

However, by the time the dosage had been reduced to $60 \mathrm{mg}$. per day, there was a slight return of symptoms, but the objective deterioration was 


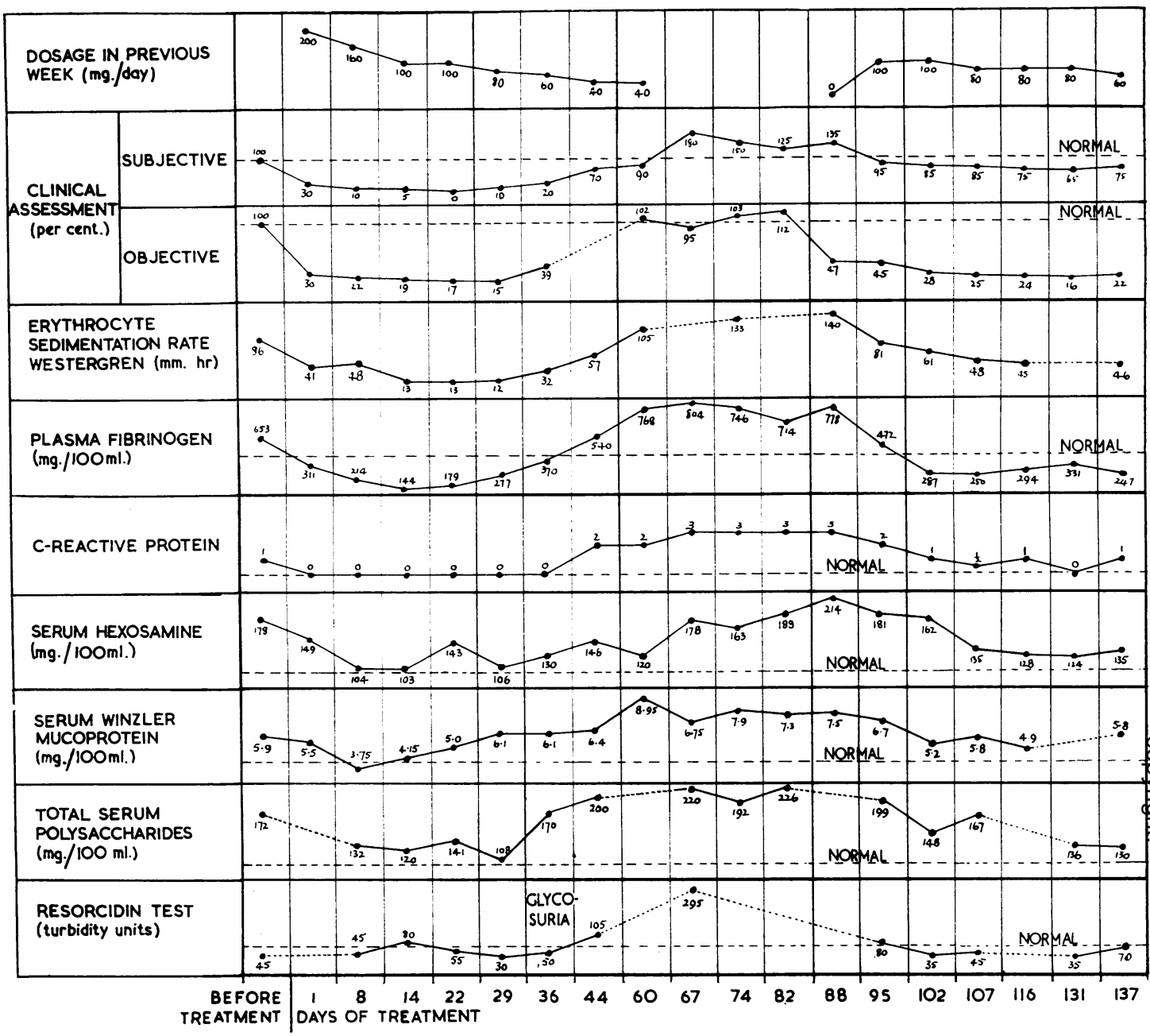

Fig. 1.-Results of tests during hydrocortisone therapy in a woman aged 60 with rheumatoid arthritis of 13 months duration.

minimal, and would normally have escaped notice or been ignored. It is therefore striking that this mild clinical relapse is reflected by a rise in no fewer than five of the laboratory tests, suggesting that the minimal suppressive dose for this phase of the disease had been passed.

Unfortunately, it was not possible to study the effect of raising the dose again at this stage, since almost simultaneously a considerable quantity of sugar was found in her urine on routine testing. The dose was reduced to $40 \mathrm{mg}$. per day and subsequently withdrawn to enable the carbohydrate metabolism to be fully investigated. The clinical relapse was immediate and devastating, and was more than reflected by the rapid rise in the laboratory indices, in most cases to above their pre-treatment levels.

It was soon apparent that this patient's abject misery, together with the rapid visceral and systemic spread of her disease, would justify a resumption of steroid treatment despite the hazards and problems which are implicit in treating a diabetic with these drugs.

Accordingly hydrocortisone was recommended 5 weeks later with a dosage of $100 \mathrm{mg}$. per day. On this occasion, there was again a marked objective improvement in the condition of her joints, but the patient insisted that despite this she felt extremely ill and that her muscles were very weak. A muscle biopsy performed at this time, revealed a generalized 
panarteritic reaction very similar to that described by Robinson, French, and Duff (1953). It is disturbing to speculate on our responsibility for this development by our rapid fluctuation of dosage.

In view of the marked discrepancy between the arthritic and the systemic response during this second phase of treatment, it is of interest to note again that whilst the " $\mathrm{C}$ "-reactive protein and the plasma fibrinogen responded rapidly and returned virtually to normal, the hexosamine, mucoprotein, and polysaccharide levels remained obstinately and significantly raised throughout. The subsequent history was one of inexorable deterioration.

Fig. 2 concerns a 58-year-old woman with a 10-month history of severe rheumatoid arthritis whose response was almost the exact antithesis of that described above. The disease was extremely active at the commencement of treatment, and this clinical assessment was supported by all of the laboratory tests.

The clinical response was rapid and extremely satisfactory. Unlike the other cases in the series, however, she showed no tendency to relapse as the dose was progressively lowered. The treatment with hydrocortisone either precipitated or coincided with a remission in the disease throughout the subsequent period of observation.

It is of particular interest, therefore, that this is also the only case in the series in which the Winzler mucoprotein remained within normal limits for long

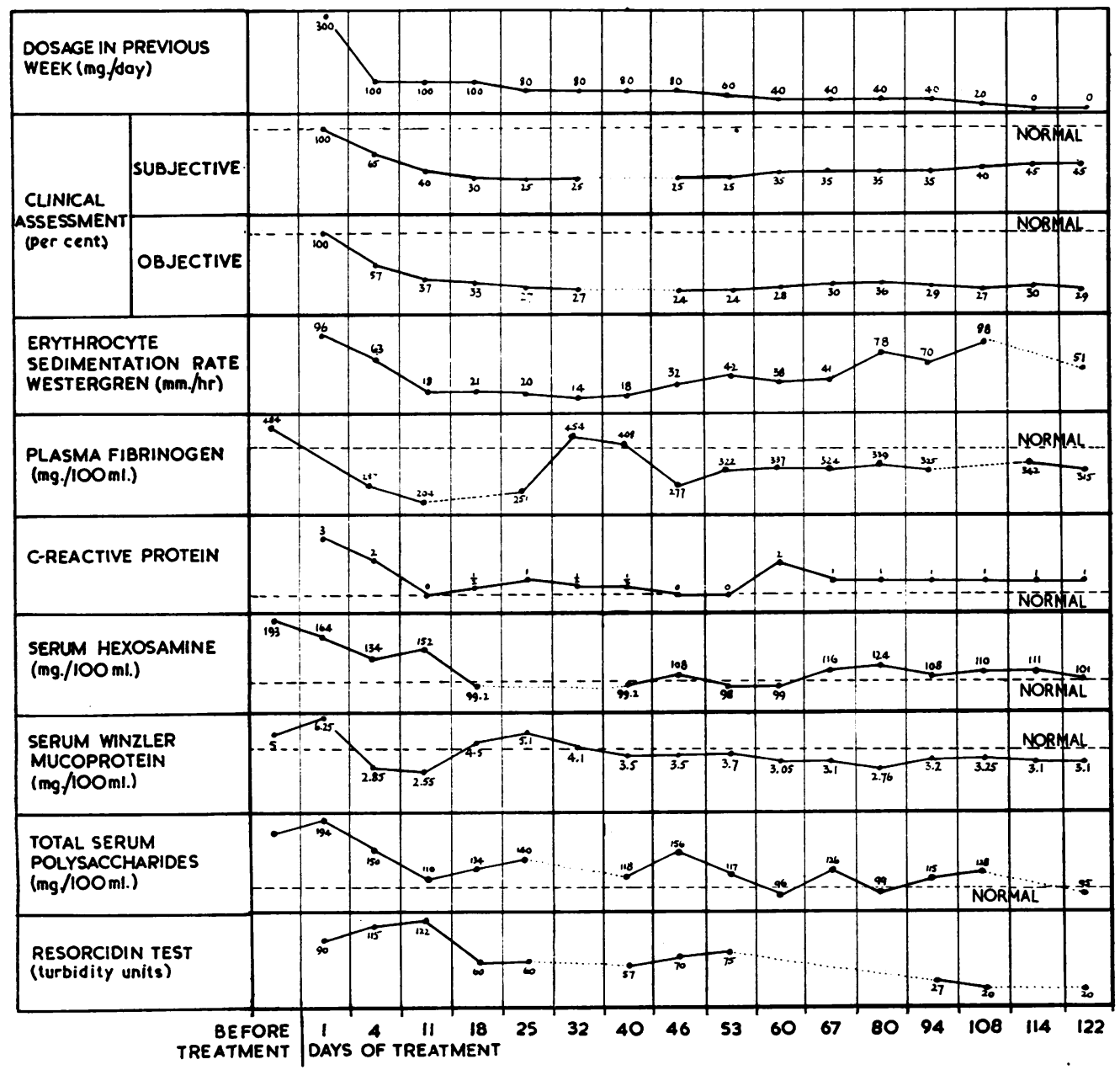

Fig. 2.-Results of tests during hydrocortisone therapy in a woman aged 58 with rheumatoid arthritis of 10 months duration. 
periods. The serum hexosamine and the total polysaccharides also remained around normal levels more consistently than in any of the other cases. The other six patients all responded in substantially the same way; Tables II and III illustrate the trends of the average levels of mucoprotein 1 and 2 months after the commencement of treatment.

\section{Discussion}

Certain conclusions may be drawn from the results obtained in this study:

(1) Active rheumatoid arthritis appears to be consistently associated with abnormally high levels of all the indices studied. Furthermore, there seems to be a crude relationship between the clinical measurement of disease activity and the extent to which these levels are raised.

(2) There were extremely few abnormal readings in normal "control" subjects or in patients found to be suffering from insignificant or localized conditions. This observation suggests that it might be possible to adapt these tests for routine "screening" purposes in busy rheumatism clinics.

(3) All the raised indices could be consistently reduced towards normal by adequate treatment with cortisone or hydrocortisone. In most cases, any cessation or reversal of this downward trend was an ominous sign that the dosage had been reduced too far for satisfactory suppression of the symptoms.

(4) It seems significant that, as shown in Tables II and III, the average levels of hexosamine and mucoprotein remain persistently above normal despite a dosage which would be considered excessively high by present-day standards. It is also interesting that the average pre-treatment levels in the eight cases studied were substantially higher than in the unselected group. This was undoubtedly a true reflection of the fact that the patients chosen for study were those with very active and progressively deteriorating arthritis.

Unfortunately, it cannot be claimed that any of the tests were reliable enough in individual cases to recommend their routine clinical use. Certainly they could not be trusted as indications of those subtle changes in dose requirements which are vital in the control of problem cases, and to which Hench has given the graphic name "dose tailoring".

It may be, however, that the mucoproteins and hexosamine could be usefully employed in distinguishing between disease remission and the artificial suppression of signs and symptoms.

With regard to their usefulness as "screening tests" for new "anti-rheumatic" drugs, the evidence is also slender but encouraging. For example, one of the patients was treated for 4 days with large daily doses of $150 \mathrm{mg}$. "Cortisone Stearate" for which the manufacturers were claiming therapeutic potency. This substance appeared to have no clinical effect on the patient, and this was reflectedco in the complete absence of response in the sero-? logical indices.

In striking contrast, another patient in the series

TABLE II

SERUM MUCOPROTEIN LEVELS IN NORMAL CONTROLS AND IN CASES OF RHEUMATOID ARTHRITIS IN DIFFERENT PHASES OF TREATMENT

\begin{tabular}{|c|c|c|c|c|c|}
\hline \multirow{2}{*}{$\begin{array}{c}\text { Serum } \\
\text { Mucoprotein } \\
\text { Level } \\
(\mathrm{mg} . / 100 \mathrm{ml} .)\end{array}$} & \multirow{2}{*}{ Normals } & \multirow{2}{*}{$\begin{array}{c}\text { Untreated } \\
\text { Unselected } \\
\text { Rheumatoid } \\
\text { Arthritics }\end{array}$} & \multicolumn{3}{|c|}{$\begin{array}{l}\text { Selected Series of Severe Rheumatoid Arthritics } \\
\text { Treated with Cortisone or Hydrocortisone }\end{array}$} \\
\hline & & & $\begin{array}{c}\text { Before } \\
\text { Treatment }\end{array}$ & $\begin{array}{l}\text { After } 1 \text { month of } \\
\text { Treatment }\end{array}$ & $\begin{array}{l}\text { After } 2 \text { months of } \\
\text { Treatment }\end{array}$ \\
\hline $2-2 \cdot 9$ & 5 & 4 & - & - & - \\
\hline $3-3 \cdot 9$ & 8 & 9 & - & - & 1 \\
\hline $4-4 \cdot 9$ & 5 & 7 & - & 2 & 3 \\
\hline $5-5 \cdot 9$ & - & 8 & 2 & 4 & 1 \\
\hline $6-6 \cdot 9$ & - & 8 & 2 & 1 & 3 \\
\hline $7-7 \cdot 9$ & - & 1 & 3 & 1 & - \\
\hline $8-8 \cdot 9$ & - & 2 & - & - & - \\
\hline $9-9 \cdot 9$ & 一 & 1 & 1 & - & - \\
\hline Total $\quad \ldots$ & 18 & 40 & 8 & 8 & 8 \\
\hline Average . $\ldots$ & $3 \cdot 5$ & $5 \cdot 1$ & $7 \cdot 0$ & $5 \cdot 7$ & $5 \cdot 25$ \\
\hline
\end{tabular}


was treated for 3 days with daily doses of $80 \mathrm{mg}$. "Cortisone Aldehyde" before being transferred to the conventional hydrocortisone free alcohol. His clinical response, though not dramatic, was easily measurable, and six of the seven laboratory indices showed a parallel fall.

Perhaps the most striking result of this study has been the sharp contrast between the lability of tests such as the erythrocyte sedimentation rate, " $C$ "reactive protein, fibrinogen, and resorcidin, and the obstinacy of indices such as the serum hexosamine, Winzler mucoprotein, and total protein-bound polysaccharides. The latter group of tests was not affected by evanescent fluctuations in the disease activity and, as already indicated, seldom reached normal levels in our patients.

It is tempting to argue from this observation that, although all the tests are non-specific in the sense that they can be affected by many different diseases, there is a suggestion of a fundamental distinction between them. This may be related to the fact that in the second group we are measuring the serological analogues of the intercellular ground substance.

We know that in the rheumatic diseases there is a profound alteration in this connective tissue and, although this is not clearly defined, it has been suggested that it takes the form of a depolymerization of the mucopolysaccharides which constitute the ground substance. There is further experimental evidence (Pirani and Catchpole, 1951) that, when these glycoproteins are depolymerized (as for example in scurvy), they become more watersoluble, and that this is reflected in a rise in their serum concentration. Finally, it is well established that one of the actions of cortisone and its analogues is to antagonize the depolymerizing action of hyaluronidase on hyaluronic acid, which is one of the essential constituents of the ground substance (Winter and Flataker, 1950).

These facts can be welded into a plausible hypothesis suggesting that the measurement of the concentration of circulating serum glycoproteins does provide a logical index of underlying disease activity in patients suffering from rheumatoid arthritis. In addition, the influence exerted upon them by the steroid drugs may well be a true reflection of their "anti-rheumatic" action. Further investigation of this hypothesis seems justified.

None of these tests measure a pure chemical substance, therefore it is of interest to determine the degree to which their levels are correlated. The coefficient of correlation between the Winzler mucoproteins and the total protein-bound polysaccharides was only $0 \cdot 62$. To some extent this relatively low figure can be explained on a purely technical basis. It has been discussed in greater detail in a previous communication (Badin and Glyn, 1954), and the conclusion reached was that the correlation was better at the commencement of treatment and that most of the discrepancies occurred in the falling portions of the curve. From this it was inferred that the synthesis of these two

TABLE III

SERUM HEXOSAMINE LEVELS IN NORMAL CONTROLS AND IN CASES OF RHEUMATOID ARTHRITIS IN DIFFERENT PHASES OF TREATMENT

\begin{tabular}{|c|c|c|c|c|c|}
\hline \multirow{2}{*}{$\begin{array}{c}\text { Serum } \\
\text { Hexosamine } \\
\text { Levels } \\
(\mathrm{mg} . / 100 \mathrm{ml} .)\end{array}$} & \multirow[b]{2}{*}{ Normals } & \multirow{2}{*}{$\begin{array}{c}\text { Untreated } \\
\text { Unselected } \\
\text { Rheumatoid } \\
\text { Arthritics }\end{array}$} & \multicolumn{3}{|c|}{$\begin{array}{l}\text { Selected Series of Severe Rheumatoid Arthritics } \\
\text { Treated with Cortisone or Hydrocortisone }\end{array}$} \\
\hline & & & $\begin{array}{l}\text { Before } \\
\text { Treatment }\end{array}$ & $\begin{array}{l}\text { After } 1 \text { month of } \\
\text { Treatment }\end{array}$ & $\begin{array}{l}\text { After } 2 \text { months of } \\
\text { Treatment }\end{array}$ \\
\hline $80-89$ & 3 & 2 & - & - & - \\
\hline $90-99$ & 8 & 2 & - & 2 & - \\
\hline $100-109$ & 5 & 2 & - & - & 1 \\
\hline $110-119$ & 1 & 2 & - & 1 & - \\
\hline $120-129$ & - & 6 & - & 1 & 一 \\
\hline $130-139$ & - & 8 & - & 2 & 2 \\
\hline $140-149$ & - & - & 1 & 1 & 3 \\
\hline $150-159$ & - & 3 & 1 & 1 & 1 \\
\hline $160-169$ & - & 3 & 2 & - & 1 \\
\hline $170-179$ & - & 1 & 4 & - & - \\
\hline Total $\quad \ldots$ & 17 & 30 & 8 & 8 & 8 \\
\hline Average $\quad \ldots$ & 98 & 122 & 166 & 125 & 141 \\
\hline
\end{tabular}


substances was probably under common control but that their catabolism took place along different pathways.

With regard to the mucoproteins and the hexosamine, the high degree of correlation is shown in Fig. 3 which refers to patients who were under treatment at the time of study. Exactly the same picture, however, was demonstrated in patients not undergoing any form of therapy.

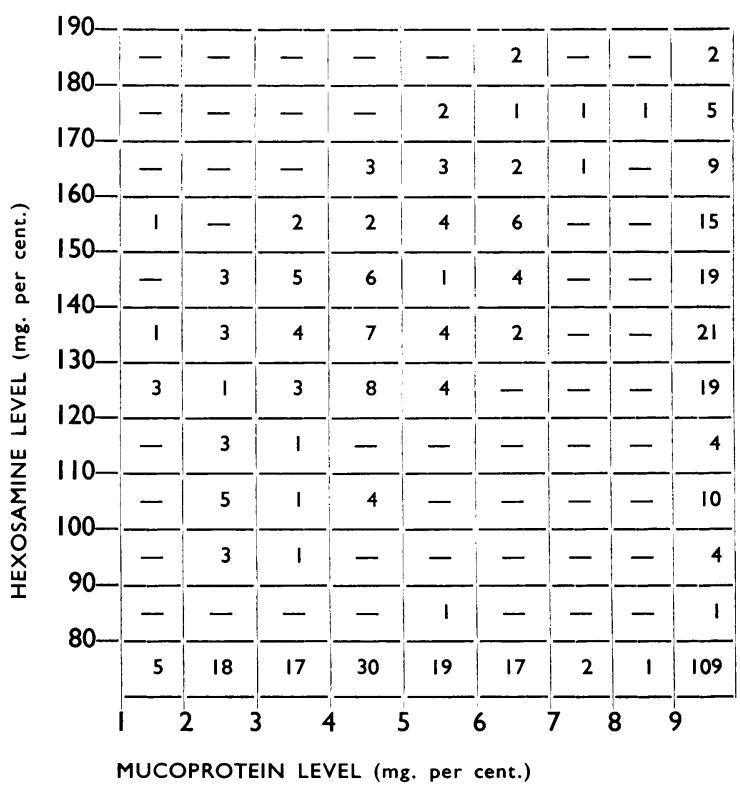

Fig. 3.-Mucoprotein and hexosamine levels in 109 patients with rheumatoid arthritis treated with cortisone.

To a limited extent the correlation can be explained by the finding of Winzler, Devor, Mehl, and Smyth (1948), and Winzler and Smyth (1948) that his mucoprotein fraction contained 11.9 per cent. of hexosamine, but on the basis of his figures it can be calculated that this source of hexosamine cannot account for more than about 10 to 12 per cent. of the total amount present. This is certainly not sufficient to explain the degree of correlation which has been demonstrated. There is, therefore, a strong suggestion of a common source of origin for these two substances, or at least certain common factors controlling their blood levels.

\section{Summary}

An attempt has been made to apply a battery of "acute phase" serological estimations to the pro- blems of controlling long-term steroid therapy in rheumatoid arthritis. The results were disappointing from the point of view of their application to individual cases, but several interesting features emerged about the interpretation of these tests and their possible relationship to one another, and to the underlying disease process. These are discussed in some detail.

A numerical method of recording and comparing subjective and objective clinical fluctuation in rheumatoid arthritis is described. It gives consistent results, at least in short-term therapeutic trials.

The material which forms the basis of this paper was obtained during the tenure of a Masonic Fellowship on the Study Group on Rheumatic Diseases, New York University, Bellevue Medical Centre. The author wishes to record his sincere gratitude for the advice and encouragement he has received from many colleagues and specifically from Drs. Currier McEwen and Morris Ziff who sponsored the project.

\section{REFERENCES}

Adams, F. H., and Dwan, P. F. (1950). J. Lancet, 70, 389.

Anderson, H. C., and McCarty, M. (1950). Amer. J. Med., 8, 445.

Badin, J., and Choukroun, J. (1950). Sem. hôp. Paris, 26, 122 and 1243.

— and Glyn, J. (1954). Proc. soc. exp. Biol. (N.Y.), 86, 150.

- Jackson, C., and Schubert, M. (1953). Ibid., 84, 288.

Bagnall, A. W. (1951). Canad. med. Ass. J., 65, 125.

Boas, N. F., and Peterman, A. F. (1953). Proc. Soc. exp. Biol. (N.Y.), 82, 19.

- and Soffer, L. J. (1951). J. clin. Endocr., 11, 39.

Bunim, J., Kuttner, A. G., Baldwin, J. S., and McEwen, C. (1952). J. Amer. med. Ass., 150, 1273 .

Copeman, W. S. C., Savage, O., Bishop, P. M. F., Dodds, E. C. Kellie, A. E., Stewart, J. W., Glyn, J. H. H., Henly, A. A., and Tweed, J. M. (1952). Brit. med. J., 1, 397 .'

Cullen, G. E., and Van Slyke, D. D. (1920). J. biol. Chem., 41, 587

Elson, L. A., and Morgan, W. T. J. (1933). Biochem. J., 27, 1824.

Fearnley, G. R. (1951). Lancet, 2, 501

and Bunim, J. J. (1951). Ibid., 2, 1113

Fletcher, A. A., Dauphinee, J. J., and Ögryzlo, M. A. (1952). J. clin. Invest., 31, 561 .

Good, R. A., Good, T. A., Kelley, V. C., and Glick, D. (1950). Fed. Proc., 9, 178.

Ham, T. H., and Curtis, F. C. (1938). Medicine, 17, 447.

Hill, A. G. S. (1951). Lancet, 2, 807.

Kelley, V. C. (1952). J. Pediat., 40, 413.

Kirschvink, J. F., and Ely, R. S. (1952). Amer. J. Physiol., $171,738$.

Lawrence, J. S. (1953). Annals of the Rheumatic Diseases, 12, 206.

Payne, R. W., Shetlar, M. R., Bullock, J. A., Patrick, D. R., Hellbaum, A. A., and Ishmael, W. K. (1954). Ann. intern. Med., 41, 775. C. L., and Catchpole, H. R. (1951). A.M.A. Arch. Path., 51, 597 .

Ragan, C., Demartini, F., Lamont-Havers, R., Jessar, R. A. Vaillancourt, D., and Grokoest, A. W. (1952). Bull. N.Y. Acad. Med., 28, 493.

Roantree, R. J., and Rantz, L. A. (1955). A.M.A. Arch. intern. Med., 96, 674.

Robinson, W. D., French, A. J., and Duff, T. I. (1953). Annals of the Rheumatic Diseases, $12,323$.

Stollerman, G. H., Glick, S., Patel, D. J., Hirschfeld, I., and Rusoff, J. H. (1953). Amer. J. Med., 15, 645.

Vaughan, J. H., Bayles, T. B., and Favour, C. B. (1951). Proc. soc exp. biol. (N.Y.), 76, 274 .

Weimer, H. F., and Redlich-Moshin, J. (1953). Ibid., 84, 34

Winter, C. A., and Flataker, L. (1950). Fed. Proc., 9, 137.

Winzler, R. J., Devor, A. W., Mehl, J. W., and Smyth, I. M. (1948). J. clin. Invest., 27, 609 .

- and Smyth, I. M. 1948). Ibid., 27617. 
Aide du laboratoire a la thérapie stéroide

RÉSUMÉ

Un certain nombre d'anomalies sérologiques nonspécifiques associées à des processus inflammatoires ou nécrotiques a été décrit et nommé "réactions de la phase aiguë'. On a essayé d'appliquer une série de telles réactions aux problèmes de contrôle de la thérapie stéroïde à long terme, dans l'arthrite rhumatismale. Les resultats furent décevant au point de vue de leur application à des cas individuels, mais plusieurs caractères intéressants se révélèrent, relatifs à l'interprétation de ces réactions, à leur rapport entre elles et avec le processus morbide. Ces caractères sont discutés avec quelques détails.

Une méthode numérique d'enregistrement et de comparaison des fluctuations cliniques subjectives et objectives dans l'arthrite rhumatismale est décrite. Elle donne des résultats valables, au moins en ce qui concerne les essais thérapeutiques à court terme.

\section{Contribución del laboratorio a la terapia esteroide}

\section{Sumario}

Un cierto número de anomalías serológicas no específicas, asociadas a procesos inflamatorios o necróticos fué descrito y nombrado "reacciones de la fase aguda". Una serie de tales reacciones fué aplicada a problemas de control de la terapia esteroide de plazo largo en la artritis reumatoide. En su aplicación a casos individuales, los resultados fueron mediocres, pero se hicieron observaciones interesantes respecto a la interpretación de estas reacciones, las relaciones entre ellas y con el proceso mórbido. Estas observaciones se discuten detalladamente.

Se describe un método numérico para notar y comparar las fluctuaciones clínicas subjetivas y objetivas en la artritis reumatoide. Este método ofrece resultados válidos, a le menos en los ensayos terapéuticos de plazo corto. 